Sida, C., Moldovan, S.-S. (2021). Cyclicity in creation: from abstraction to figurative, from figurative to abstract. Scientific view on the modern problems of cultural heritage and arts in the context of social development. Klironomy, 1 (01), 127-137. Hlučín-Bobrovníky: “Anisiia Tomanek” OSVČ.

Sida, C., Moldovan, S.-S. (2021). Ciclicitate în creaţie: de la abstractizare la figurativ, de la figurativ la abstract. Scientific view on the modern problems of cultural heritage and arts in the context of social development. Klironomy, 1 (01), 127-137. Hlučín-Bobrovníky: "Anisiia Tomanek” OSVČ.

DOI: $10.47451 /$ art2021-04-003

EOI: $10.11249 /$ art2021-04-003

The paper is published in Crossref, Internet Archive, Google Scholar, Academic Resource Index ResearchBib, JGate, ISI, CiteFactor, ICI, eLibrary databases.

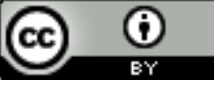

Cristian Sida

Associate Professor, Doctor in Visual Arts

Department of Visual Arts

Faculty of Arts and Design

West University Timisoara

Timisoara, Romania

E-mail: cristian.sida@e-uvt.ro

Smaranda-Sabina Moldovan

Assistant, Doctor in Visual Arts

Department of Visual Arts

Faculty of Arts and Design

West University Timisoara

Timisoara, Romania

E-mail: smaranda.moldovan@e-uvt.ro

\title{
Cyclicity in creation: from abstraction to figurative, from figurative to abstract
}

\section{Abstract:}

The paramount focus of this article shall be on painting, mainly that of contemporary artists, but apprehending back to their modern predecessors without which some of the aforementioned contemporary painting figurative/abstract would have been inconceivable. The research of the identification of some directions in painting, both in the creative process and in the educational one, is a difficult objective to achieve. The hierarchy and classification of some tendencies, as plastic formulas, represents a challenge only if we consider that any artist crosses over, during his artistic career, several stages of creation. At the same time, the present research aims to bring to attention one of the most significant examples of relating the topicality of artistic creation, with amplifying and renewing the horizon of artistic higher education. These aspects are always, or should be integrated in the teaching of each artist who teaches in art higher education institutions. The authors' cases are important because they can reveal different aspects of the creation process that on one hand can start with abstraction and find the figurative in it, and on the other hand it can have its roots in reality, a reality that is reduced in simple abstract forms by the process of 
abstraction. Both cases have interdisciplinary aspects from psychology, philosophy and are related with other aspects of human activity such as memory, imagination, abstraction.

Keywords: painting, avantgarde, contemporary painting, ready-made, assemblage, object painting, art theory, dadaism, neo dadaism.

Cristian Sida

Conf.univ.dr.

Departamentul de Arte Vizuale

Facultatea de arte şi design

Universitatea de Vest

Timişoara, România

E-mail: cristian.sida@e-uvt.ro

Smaranda-Sabina Moldovan

Asist.univ.dr

Departamentul de Arte Vizuale

Facultatea de arte şi design

Universitatea de Vest

Timişoara, România

E-mail: smaranda.moldovan@e-uvt.ro

\section{Ciclicitate în creație: de la abstractizare la figurativ, de la figurativ la abstract}

\section{Abstract:}

Accentul principal al acestui articol se va pune pe pictură, în principal pe cea a artiştilor contemporani, dar înţelegând predecesorii lor moderni fără de care unele dintre picturile contemporane menționate din zona figurativ / abstract ar fi fost de neconceput. Cercetarea identificării unor direcții în pictură, atât în procesul creativ, cât şi în cel educațional, este un obiectiv dificil de realizat. Ierarhia şi clasificarea unor tendințe, ca formule plastice, reprezintă o provocare doar dacă considerăm că orice artist traversează în cursul carierei sale artistice, mai multe etape ale creației. În acelaşi timp, prezenta cercetare îşi propune să aducă în atenție unul dintre cele mai semnificative exemple de relaţionare a actualității creației artistice, cu amplificarea şi reînnoirea orizontului învăţământului artistic superior. Aceste aspecte sunt întotdeauna incluse sau ar trebui integrate în predarea fiecărui artist care predă în instituțiile de învățământ superior de artă. Cazurile autorilor sunt importante deoarece pot dezvălui diferite aspecte ale procesului de creație care, pe de o parte, pot începe cu abstractizarea şi pot găsi figurativul în ea şi, pe de altă parte, îşi pot avea rădăcinile în realitate, o realitate care se reduce în forme abstracte simple prin procesul de abstractizare. Ambele cazuri au aspecte interdisciplinare din psihologie, filosofie şi sunt legate de alte aspecte ale activităţii umane, cum ar fi memoria, imaginaţia, abstractizarea.

Keywords: pictură, avangardă, pictură contemporană, ready-made, asamblare, pictură-obiect, teorie artei, dadaism, neo dadaism. 


\section{Introduction}

From the first artistic manifestations, from the engraved shells made by Homo Erectus in the cages of Altamira and Lascaux until now, man has been preoccupied with creating images. The aesthetic and stylistic mutations that the plastic image has undergone throughout history, due to the evolution of society, the evolution of technology, and last but not least, the spiritual evolution are the main topic of this article. Lithuanian choreographer Mikalojus Konstantinas Čiurlionis and supremacist painter Pavel Mansurov both perform as painters and musicians during the same period, being considered to be the first to make abstract artworks even before Wassilly Kandinsky. Employed in this double position, they are among the first to be interested in the multidisciplinary nature of the arts and have probably premeditated the interaction that will have the fields related to the visual arts in the twentieth and twenty-first centuries.

The line has always been a constant in plastic representation, often drawing the invisible boundaries of creation. From the moment she is born from the point, it moves, describes a parable, has her own life. Her trajectory changes with style: Geometry in Muslims, baroque in the Vikings, supple in the arabesques of the 21st century, rested in Jean Auguste Dominique Ingres's creation, declamatory in Eugene Delacroix's paintings, becomes tense in the twentieth century, and we find it 'raw' in the creations of Pablo Picasso or Jean-Michel Atlan. Also, in the second half of the twentieth century, the line is a dominant element under various connotations like the playful-fantastic in works of Juan Miro, romantic and musical in Hans Hartung. (Ragon, 1969). The stain is in a relationship of subsidiarity with the line, in a fruitful complicity to create rhythms, conceived as if also from the entropy of the Universe, it is a fundamental element in the construction of the plastic image. Two other essential components in the creation of the painting are matter and color. Matter exists by itself, and color cannot exist without matter.

The Bauhaus phenomenon would therefore make a major contribution to the development of modern art education in both Europe and the United States, through the exile of the founder of the movement, Walter Gropius, overseas. The New Bauhaus, an educational, inspiring and stimulating factor for artists, designers or architects, will transmit among artists members of the Vitebsk School (Marc Chagall, Yuri Pen, Kasimir Malevich, El Lissitzky) ideas about line, point, stain, surface, space and the existence of an original and revolutionary style. Dadaist or neo-Dadaist manifestations may now seem quite accessible, if we look at their arrogant recoveries, called postmodern today. 
Characterized by frond and ambiguity, the artistic avant-garde, especially Dadaism, imposes a new positioning of the public vis-à-vis the visual arts, and an aesthetic based on the supremacy of the 'ready-made' object. The object, or the painting object is dispossessed of conventional attributes (Man Ray, Marcel Duchamp) and placed rather in the area of a forced and intriguing imaginary.

Collage, assembly, decal, rubbing, oversizing the object, will be common ways of representation since 1917, both in the practices of Dadaism, Neo Dadaism and Surrealism. Subsequently, a large part of the conceptual artists will be tributary to this new type of aesthetics, bringing art in the area of performing arts, so that in the end they will abolish all the borders that would separate the fine arts from the applied arts or theater or circus. 'Savoir faire' would become a taboo phrase, on the verge of extinction, while Dadaist, neo-Dadaist or conceptual artists would validate the idea that only what you do is important, not how you do it.

The impact of the artists Marcel Duchamp and Joseph Beuys and the influence that the avant-garde had on the evolution of twentieth and twenty-first century art, as well as their contribution to the assertion of the object and performance is difficult to admit and accept. Artists reimagined nature, that they distorted it, that they transposed it, that they saw it from several angles, deconstructing and reconstructing, often going to ridicule and leading the subject into derision. The whole arsenal is put at the service of creation, by approaching new techniques: collage, rubbing as Max Ernst, decal as Oscar Dominguez, assembly. Of all the avant-garde arts, Dadaism was the most important nucleus of the development of visual arts. Its derivatives from 1922 to today bear names such as: collage, montage, assembly, ready-made, arte povera, picto-object, neo dadaism, neorealism. Artists Kurt Schwitters, Jannis Kounellis, Luciano Fabro, Michelangelo, Pistoletto, Yves Klein, Daniel Spoerri, Jean Tinguely, Jan Fabre are also tributaries of Dadaism.

The artistic object (Nita, 2016), as it will delve into in this article, is a material form that exists independently of its circumstances. It can be purely physical as an object trouvee, composed in the same way as the actual objects in the assemblies or only documentary, as in conceptual art, thus existing only at the level of project or document. The two specializations of the fine arts, painting and sculpture, are unified in terms of the object, especially in Nouveaux realism and minimalism, in painting or in sculpture through the soft sculptures of Claes Oldenburg and Commodity sculptures. The classification of objects in sculpture according to Rudolf Kocsis can also be applied to painting. The three-dimensional works of Pablo Picasso, Marc Chagall, Auguste Renoire, Lucio Fontana, Alberto Giacometti presented in the catalog La sculpture des peintres, (Fondation Maeght, 1997) their appearance of object 
as assemblies (Lugli, 2000) shows that the boundary between painting and sculpture has been blurred.

This taxonomy of objects (Kocsis, 2003) includes: The object itself, called by the sculptor 'the object itself as a plastic language' that corresponds to readymade objects, found objects. They are often viewed by laymen of the field as the usual objects, which were reproduced in painting in Pompeian frescoes, culminating in the static Flemish natures, by creating an illusion of the dimensional. With cubism they developed in painting, in Gauguin the objects themselves become part of the painting; The Brentanian object (Brentano, 1973) as a process of destruction and creation, called by the sculptor 'reconsideration of the destroyed object' and for which he proposes applications from the movement of the new realists. In painting this can be a nihilistic object, which can be fragmented and then recomposed. Within this group, the pictorial and sculptural genres fade perhaps the most; 'The object as a body metaphor' with examples of the author of Picasso's work; The collage, which I also want to introduce in the category of two-dimensional gear, manifests itself in painting as composite substances; 'The fetish object', which Rudolf Kocsis indicates as the object of consumption, according to Marx's theories. In painting it is more prominent in the works of Dadaists, new realists and feminist forerunners who were in contact and developed complex relationships with consumer objects; 'Hybrid object'; The 'sign object' such as those in assemblies or performances given by representatives of feminism such as Abramovici and Piper.

The theory of Gaston Bachelard (Bachelard, 1948) sets problems of the imaginary as a space of existence. The perceived image and the created image are two very different psychic instances and a special word should be found to define the imagined image. According to Bachelard, everything connected with reproductive imagination must be attributed to the perception of memory. Creative imagination has completely different functions than reproductive imagination. The creative imagination belongs to the function of the unreal, which is psychically as useful as that of the real and often evoked by psychologists to characterize the adaptation of a spirit to a reality accepted by social values. Jean Paul-Sartre (Sartre, 2012) also explains the process of invention by the human creative spirit.

\section{Methods}

The research methods used in this article are based on experiment and study case. The modus operandi was chosen because the new derivative of the old has not gone out, but continues as a similar process as modernism and neo modernism in the social and economic contexts of each historical period. 
The experiment consists in bringing out or generating adequate conditions for the study of a certain phenomenon. (Titu, 1997) Its purpose is to observe changes due to a set of imposed conditions. In contemporary art, this type of investigation is a constant enactment, being an artistic etiquette rather than a movement. We consider it an instrument of research of an endless reality in expression, a practice of getting out from under the canon of any type of protocol, or at the minimum of the perception of already validated principles in visual arts.

The two study cases exposed are: First case is from artist and professor Cristian Sida artworks Polar Bear, 2006 and Satyricon, 2009 under the title From abstraction to figurative. The second study case involves the artworks from the doctoral studies of Smaranda-Sabina Moldovan. The second case is presented under the title From figurative to abstraction.

\section{From abstraction to figurative}

Cristian Sida has appealed after the abstract period and the semi-figurativegarnishing one (Fig. 1), with the initiation of the Satyricon cycle (Lui Tapies) (Fig. 2), a new series of paintings that have their definite origin in the Dadaist-Surrealist practices. During that time, the phrase 'utopian association' was already on the lips of all artists concerned with probing memory, introspection, experiment, inducing the creative act, stimulating the imagination both with the help of innovative plastic formulas and with the help of drugs.

He considers that one cannot talk about personal research in the field of visual arts, without referring to the activity with the students. It is a natural, even organic process, that of accumulation at the workshop, and later of transfer, in the workshop of the students from the faculty. The accumulation stage is itself determined by many factors: workload, up-to-date information, online and museum research, art galleries, identification of bibliographic material related to the creation phase and cycle of works, documentary trips, and much more. depending on the field of plastic activity.

Starting with 2009, his preoccupations would be more and more determined by a timid return to the human body, to that stylistic and anthropomorphic matrix that has been obsessing him for many years. Apparently this had manifested itself rather by chance, as a succession of pseudo-abstract attempts at a semi-figurative devoid of any shadow of transition that could have betrayed what would happened next. The change of direction during his artistic career was the visit, in the year 2006, of the Egyptian Art section to the Louvre Museum in Paris. Without this visit, his return to form would probably have been postponed. In art, the essential encounters occur when it is needed to happen and especially when necessary. This is how the Satyricon 
cycle came into being. From the ample, abstract-informal surfaces on panoramic, horizontal format, to the semi figurative constructions invested with epic meanings of Surrealist origin, and based on tributary associations of a metaphysical discourse of Giorgio de Chirico and Andrea del Savinio type, these works have practically metamorphosed to this day in what the artist would call a new visual identity.

If initially in the works made between 2003-2006 as Polar Bear, there were vague formal indications of what could be composed of a decorative frame dominated by color, in the series of works entitled Satyricon, the plastic space is populated by a unique mise-en-scene, by importing old-fashioned characters, reminiscent of the Epicurean world of the Roman Empire. The associations between human and animal, between phytomorphic and organic, between the natural anatomies and dystopias of the invented characters, the relations between the line graphics and the smear of the dominant whites brought in those works are elements that bring a new type of imaginary in his creation.

\section{From figurative to abstraction}

Smaranda Moldovan research is based on associating some already existing concepts from philosophy regarding the object, by studying the approach of the object in different currents and periods of art history and direct observation of the immediate reality. She goes for elements with which we interact in everyday life. These are usually personal objects, objects seen as product or design, found objects, images of objects and aesthetic objects. Their choice is random and without having a linearity, a system of selection.

Object n. 2 (Fig. 3, 4) is an assemblage or a soft sculpture that refers to the ephemerality of objects that leads to their accumulation. By their accumulation, in time, they settle, agglomerate, invade their space of mutual influence, reaching to be perceived as a single volume. The extraction of each object is a way of fighting back the social process of accumulation. At the same time the objects used for the artworks are real objects, like in this study case a pair of linen pants. The process of reconstruction of the shape involves a chemical process of degradation with resin. This intervention on the physical form shapes the ready-made object into an almost flat surface, making the primary object unrecognizable. The process is one of abstractization.

Abstraction is the process of creation, is for the artist a mental process in which the transition from concrete to abstract is made. The process determines the generalization of the characteristics of a group of objects. Only the characteristics and essentiality of the object or group are retained. It takes place in the preliminary 
phase of the works, in the stage of elaboration of the sketches. The process is a mental one and involves a memory factor. The procedure of abstraction is necessary, because only through this process can we reveal certain aspects more clearly, eliminating unnecessary details. Thus, through the mental decomposition of objects, their particularities are separated, they are recomposed through the synthesis process, comparisons are made between their various values already stored.

\section{Results}

The result of the two case studies reflects a trend in the creative process that may have a beginning in the abstract area, continuing later in the figurative as in the case of Cristian Sida, or a beginning in the figurative as an object found, ready-made, distorted as an abstract representation. The characters created by Cristian Sida are expressive, very subjective, they seem to be moving in the paint, while the recent assemblies in resins and other materials of Smaranda Moldovan are threedimensional translations of some radical abstractions of everyday life.

The art critic Ileana Pintilie writes about the creations of Cristian Sida in the Art Catalogue for the exhibition of Satyricon, April 2007, Calina Gallery Timișoara, Romania: "The gestures remain unfinished in the air, the dematerialized characters persist only as a contour or a transparent silhouette projected on the canvas. Between them certain connections are created, which leave the appearance of a narrative development, and the characters are highlighted as a theater scene." (Pintilie, 2007)

Smaranda Moldovan's objects, even if they have roots in the public, personal and e-media space (Moldovan, 2019) are considered by art critic Ioan Iovan as expressing a whole unit. "These objects free of form and nomination exist, moreover, as a rumor of form, they are, moreover, in the informal area." (Iovan, 2020).

\section{Discussion}

The relevance of these studies and researches is closely related both to the enrichment of the creative area of the contemporary artist, and to visual artist formation in the higher education system. We also need to educate the public to read the picture. The more or less informed public tends to confuse form with image. For example, abstract art has always confused it, because it represents nothing. In order to read the artwork we must see the plastic subject and not his literary subject, not what he tells, not the narration of the image, but its construction. The distancing of the narrative reading, linear, occurred with the French Revolution (1789) when we can say that we can speak for the first time of modern art. The painter changes, both the approach of the subjects and the workspace moving into the plein air, 
(Impressionists, Post-Impressionists). Through interdisciplinary domains as physics and chemistry, the notion of color, the theory of color (Neo-Impressionists), the break with tradition, will be total with the beginning of the twentieth century.

Almost contemporary, during cubism the decomposition of the object into several facets leads to an approach to abstractionism. Its third phase is a synthesis phase, where the image is tried to be reunited, after the severe fragmentation during the second period. The cubist movement is considered to be the nest from which modern sculpture has its roots, in the first cubist collages. Objects and fragments of objects were introduced in these collages. Pablo Picasso introduced string and the printing of a chair in his 1912 work, Wicker Chair, thus raising the issue of ordinary objects in relation to art objects.

But the movements, from modernity to our times, whether due to line or light, defragmentation and recomposion, bidimensional and tridimensional, create dynamics, rhythm. Rhythm is an essential attribute of action, responsible for the motor function of the line, is an important ingredient in the composition of the work of art: agitation, animation, movement, gesture, progression, vibration, rotation, ascent, descent; rhythm is synonymous with the image. The Swiss nouveaux realiste artist Jean Tinguely said that "the only stable thing is movement, always and everywhere".

\section{Conclusion. A cyclity in creation}

The contemporary artists took over, appropriated over time the strategies, images and forms of previous generations or movements. Thus, the topics were rethought and then through various technical interventions, both traditional and new, they were refragmented, recomposed, taken off, raising, adding or deleting in order to replenish the former with a new overture or perspective. The role of the imaginary is decisive in the rehabilitation of the figurative and implicitly of the drawing in the works from the Satyricon series of Cristian Sida. Instead in the series of Objects by Smaranda Moldovan the imaginary is reduced to the minimum and the figurative, the real object, the ready-made is on a journey to the beginning of shape, with no urge to communicate it's figurative nature. What is sure is that both have their subjective perception itself, the illusion that somehow compels you to see things that you wouldn't have to choose to look at.

\section{References:}

Bachelard, G. (1948). La Terre et les rêveries de la volonté. Paris: Jose Corti. Brentano, F. (1973). Psychology from an Empirical Standpoint. London: Routledge. 
Fondation Maeght. (1997). La sculpture des peintres. France: Saint Paul.

Iovan, I. (2020). Obiecte în sine şi imagini în diseminare. Doctoral thesis of Smaranda Moldovan. De la obiect la pictura. De la pictura la obiect. Timişoara: Timis.

Kocsis, R. (2003). Obiectul și sculptura. Timişoara: Fundația Interart Triade.

Lugli, A. (2000). Assemblage. Paris: Adam Biro.

Moldovan, S.-S. (2019). Impact of the near reality on my assemblages (Sources of the raw objects). Revista Caiete de Arte şi Design, 7, 99-106. Retrieved March 20, 2021, from https://designartpapers.ro/2020/03/21/art-design-papers-no-7-2019/

Nita, B. (2016). Ontologia operei de artă. Iaşi: Institutul european.

Pintilie, I. (2007). Expoziția Satyricon. Timişoara: Timis.

Ragon, M. (1969). 25 years of living art. Paris: Casterman.

Sartre, J.-P. (2012). L'Imagination. Paris: P.U.F.

Titu, A. (1997). Experimentul în Arta Românească după 1960. Bucureşti: Soros. 


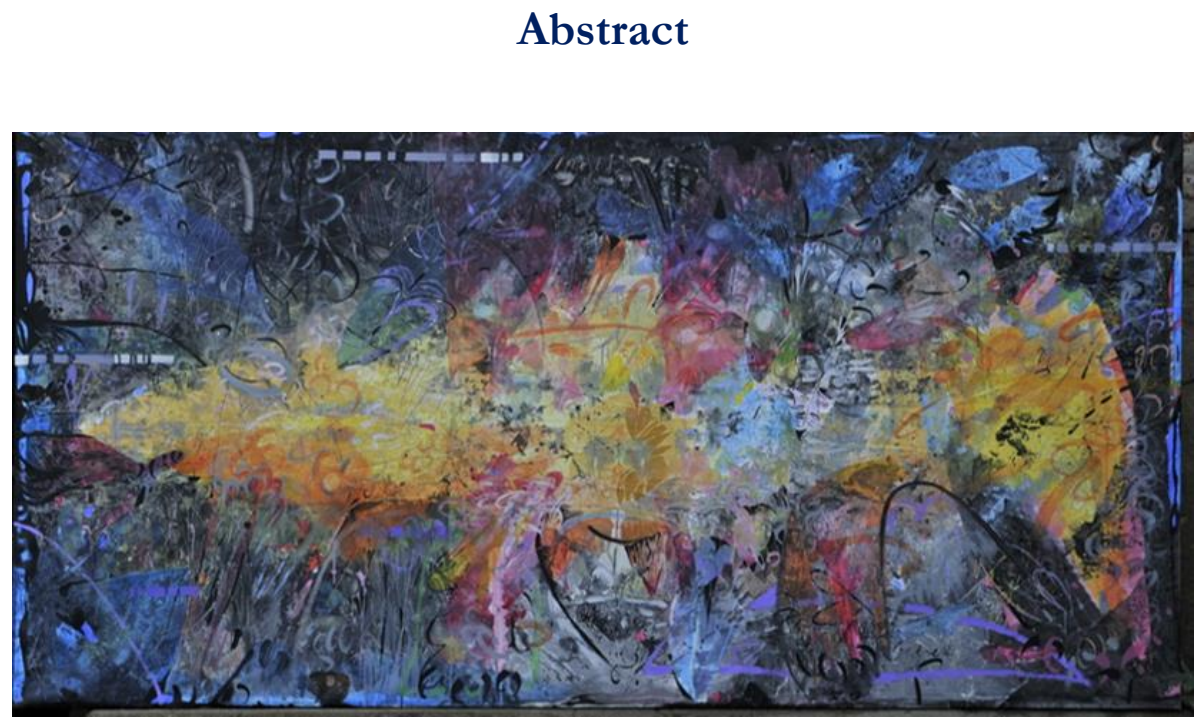

Figure 1. Urs Polar 2 / Polar Bear 2, acrylic on canvas, 300/150, 2006. Photograph from artist personal archive

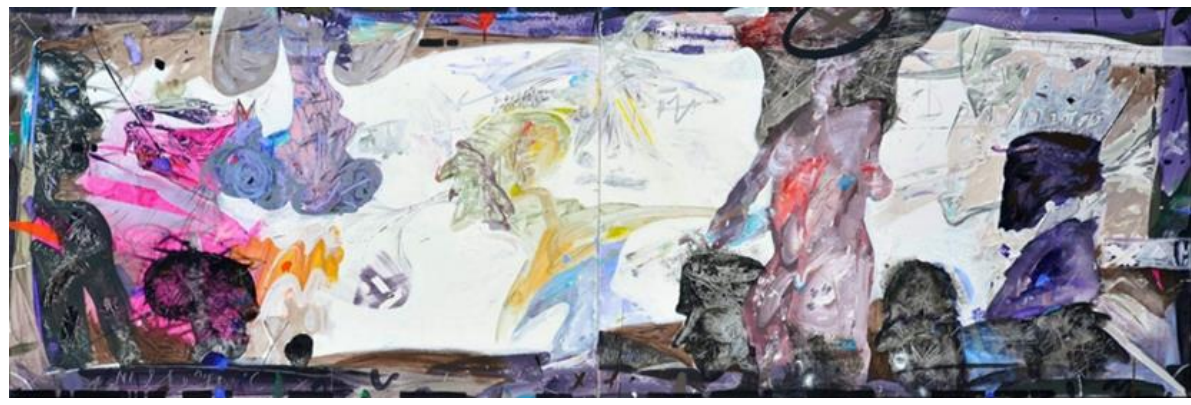

Figure 2. Satyricon (Lui Tapies) 300/100 cm, acril, marker on canvas, 2009. The artist considers it the most important moment of his creation so far. Photograph from artist personal archive
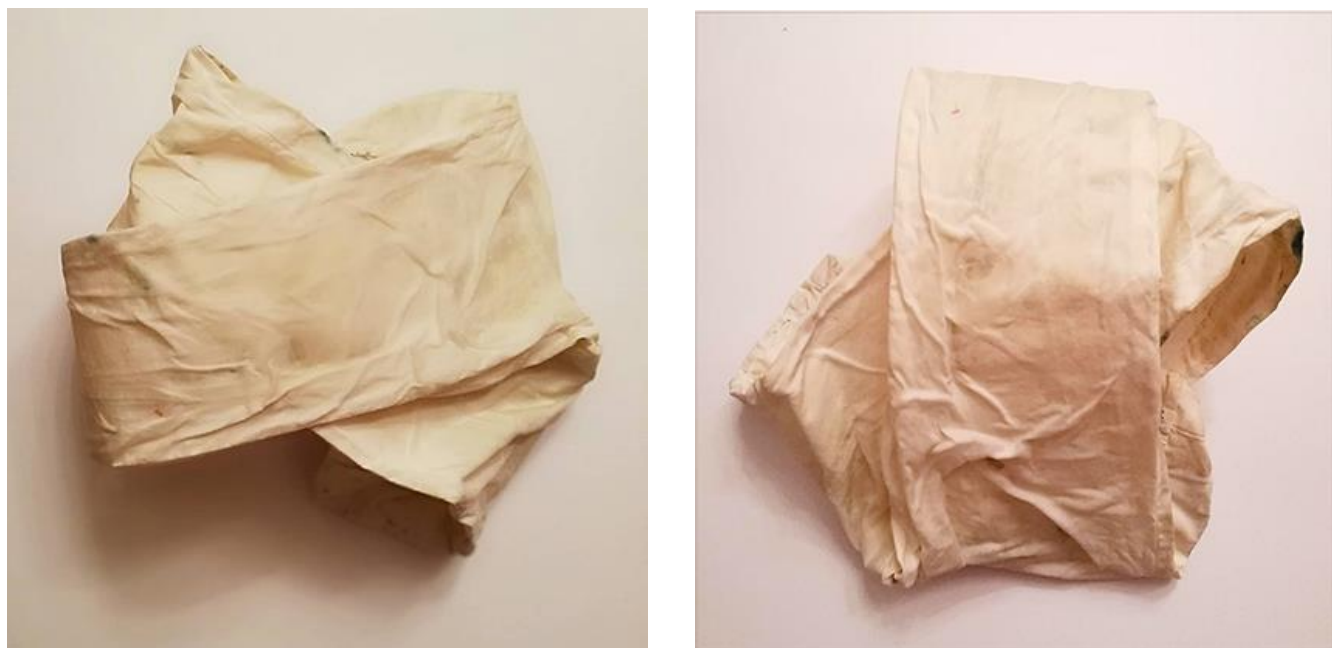

Figure 3-4. Object no. 2, assemblage, linen 